\title{
Deviant (M)others: The Construction of Teenage Motherhood in Contemporary Discourse
}

\author{
HELEN WILSON* and ANNETTE HUNTINGTON** \\ ${ }^{\star}$ FRST Bright Futures Doctoral Research Fellow, Centre for Public Health Research, \\ Massey University at Wellington, PO Box 756, Wellington, New Zealand \\ ${ }^{*}$ Contact author: Associate Professor, School of Health Sciences, Massey University at \\ Wellington, PO Box 756, Wellington, New Zealand \\ email: a.d.huntington@massey.ac.nz
}

\begin{abstract}
Paradoxically, the focus on teen motherhood as an object of concern in the West has coincided with declining rates of teen birth. This suggests that the view of teenage motherhood as problematic is underpinned by changing social and political imperatives regarding the role of women in these countries. This article examines the literature surrounding teenage motherhood from the United States, United Kingdom and New Zealand, and explores the way in which normative perceptions of motherhood have shifted over the past few decades to position teenage mothers as stigmatised and marginalised. Two specific discourses - those of welfare dependency and social exclusion - are highlighted, and their mediation through scientific discourses examined. The increasing trend to evidence-based policy development has masked the ideological basis of much policy in this area and highlights the importance of critical evaluation of the discourses surrounding teenage motherhood. A critical examination of the literature suggests that teenage mothers are vilified, not because the evidence of poor outcomes for teen mothers and their children is particularly compelling, but because these young women resist the typical life trajectory of their middle-class peers which conforms to the current governmental objectives of economic growth through higher education and increased female workforce participation.
\end{abstract}

\section{Introduction}

Paradoxically, the recent constitution of teenage motherhood as an object of concern in the developed countries of the West has coincided with declining teen birth rates. This suggests that the view of teenage childrearing as problematic is largely underpinned by changing social and political imperatives regarding the role and responsibilities of women in Western society. The pattern of higher education, the establishment of a career, and then (perhaps) starting a family, for contemporary middle-class women has gradually become normative, while those young women who do not follow this trajectory - or do so in a different order - have become the targets of marginalisation and stigmatisation. 
What follows is a critical exploration of the discourses surrounding teenage motherhood, drawing on the literature from the United Kingdom (UK), United States (US) and New Zealand (NZ): countries with high but declining rates of teen births (Unicef, 2001). The focus is on these three countries because these declining rates have been inversely mirrored by a growing preoccupation with and anxiety about teen motherhood in these areas. This concern is primarily articulated through the interrelated discourses of welfare dependency and social exclusion, and legitimised through scientific discourse. The increasing trend to evidence-based policy development has masked the ideological basis of much policy in this area and highlights the importance of critical evaluation of the discourses surrounding teenage motherhood, particularly since service provision and delivery largely reflect policy decisions.

Although the teenage years cover a wide age range, the term teenage (or adolescent) mother is used loosely in the media, and in governmental and scientific reports. In relation to teenage motherhood, there is a tendency not to distinguish older from younger, married from unmarried, and self-supporting from welfare-dependent teen mothers. As a result, the term teenage motherhood is generally understood to encompass all teenage mothers, regardless of age and marital and economic status, whether this is the intention or not, and the implication is that there are identical outcomes. For this reason, the term teenage mother has been used throughout this article.

\section{The emergence of the teenage $(\mathrm{m})$ other}

Until the late 180os, the notion of adolescence as a stage of life between childhood and adulthood was non-existent. It was only in early industrial society when young people left the influence and control of their families and migrated to the cities to work as apprentices, domestic servants and factory hands that we see its emergence as a new developmental stage (Griffin, 1993). According to Ariès (1973), it was this transition from dependence to independence which was responsible for constituting a new 'age' between childhood and adulthood. However, this period of life has always been viewed with some anxiety by adults, from its first construction as the 'criminal age' in the early 2oth century (Stanley Hall, 1904: 325 ) to the 'dangerous age' of the late 2oth century (Ritchie and Ritchie, 1984). In particular, the notion of 'juvenile delinquency' which emerged during the late 188 os became the focus of increasing concerns about adolescent behaviour during the early 2oth century (Neale, 1924; Burt, 1938), prompting, in New Zealand for example, both a research study (Philipp, 1946) and an official government inquiry (Special Committee on Moral Delinquency in Children and Adolescents, 1954).

It is likely that the economic independence of 2oth century youth and the social freedom this brought, which posed a challenge to adult control, was largely responsible for the way in which adolescence has, as Griffin claims, been 
consistently pathologised by adults (1993: 25). This is supported by comments, such as those made in an early parliamentary debate in New Zealand on contagious (or sexually transmitted) diseases, criticising the behaviour of young women 'who must go to factories, preferring that to service; they must go to factories when they would go out in the streets and walk about at night; temptation was put in their way, and the social evil was increased' (NZPD, 1885: 221, citing the Hon. Mr McLean).

Such concerns are frequently underpinned by an anxiety about sexuality, particularly female sexuality. This is epitomised by contradictory discourses in which girls can be seen by the same writer as the 'easy prey' of men one month (Cunnington, 1916a:7) and the next as preying 'on the susceptibilities and passions of young manhood' (ibid. 1916b: 7). Today, a glance at newspapers in New Zealand indicates how entrenched such attitudes have become with frequent and dramatic headlines such as 'Teen abortions in thousands' (Robertson, 1998), 'Teen pregnancy, STDs “a crisis"' (Andrew, 2000), 'Chlamydia found in high schools' (Van Beynen, 2001), 'Teens binge-drinking more' (Paltridge, 2002) and the grossly inaccurate banner headline 'Maori teenage birth rate soars' at a time when this was declining (Samson, 2000). Although the language may be gender neutral, on close reading it is obvious that reference is primarily to the behaviour of teenage girls.

This focus on female behaviour as problematic persists into the role of motherhood. Since the Cartesian separation of mind and body in the mid 160os, Western thinking has been dogged by dualistic views of humans and human behaviour. Motherhood has long been a favourite target with the good/bad mother dichotomy a key feature of maternal discourses. Mothers who fail to meet normative expectations of the role of mothering inevitably are positioned as the deviant 'other' and considered to be unfit to parent. These perceptions are historically and culturally specific, with past constructions of the deviant mother associated with poverty and/or illegitimacy. For example, in the discussion on bastardy in the British Poor Law Report of 1834, one witness said of the mothers, 'They don't in reality keep the children; they let them run wild, and enjoy themselves with the money' (cited in Checkland and Checkland, 1974: 267). Later, around the turn of the 19th century, the prevention of births to these women became one of the main objectives of the 'scientifically' based eugenics movement which was active in a number of Western countries including the UK, US and NZ1 (Chapple, 1903; MacKenzie, 1981; Allen, 1995).

However, with regard to teenage motherhood, this negativity has not generally been evident. Until recently the teenage years were considered an optimal time physiologically for childbirth (Walker et al., 1976) with no suggestion that they might be problematic for other reasons, while a mother over the age of thirty was considered to pose particular problems (Myles, 1968). This situation has now been reversed as older mothers have become the norm ${ }^{2}$ and the multiple 
problems associated with later fertility, demonstrated by the rapidly increasing demand for IVF treatment and egg-freezing services, tend to be overlooked, while teenage mothers as a group have become increasingly marginalised and stigmatised in the same way that unmarried mothers of all age groups were in the past.

Consequently, in marked contrast with the joyful event that normally characterises childbirth and which is the experience of many young mothers (Lamanna, 1999), teenage motherhood is now invariably positioned as a social or public health problem throughout the scientific literature (Holt and Johnson, 1991; Hoffman et al., 1993; Maynard, 1997; Corcoran et al., 2000; Dickson et al., 2000; Fergusson and Woodward, 2000; Jaffee et al., 2001; Scally, 2002). This view is based on studies which show that teenage motherhood can result in an increased risk of adverse obstetric outcomes (Fraser et al., 1995; Botting et al., 1998), higher rates of poverty and/or curtailment of schooling (Card and Wise, 1978; Williams et al., 1987; Grogger and Bronars, 1993; Hoffman et al., 1993; Howard, 1999), lower rates of workforce participation (Grogger and Bronars, 1993), increased welfare recipience (Grogger and Bronars, 1993), and a variety of poor outcomes for offspring (Peckham, 1993; Grogger, 1997; Moore et al., 1997; Coley and Chase-Landale, 1998; Fergusson and Woodward, 1999; Jaffee et al., 2001). With few exceptions (Campbell, 2001; Turia, 2004; YWCA, 2004), this negativity is consolidated through the media in the UK (Slater, 1999; Allison and Hall, 2001) and NZ (Samson, 2000; Schnauer, 2000; Newman, 2001) and in policy documents and reports both in NZ (Ministry of Health, 1998; Department of Corrections, 2001; Ministry of Social Policy, 2001; Jacobsen et al., 2002; Ministry of Social Development, 2004) and internationally (Social Exclusion Unit, 1999; Unicef, 2001; OECD, 2003). At times, teen motherhood is implicated by its juxtaposition with suicide, crime and/or drug-taking (see Jacobsen et al., 2002; OECD, 2003).

Paradoxically, however, the recent constitution of adolescent childbirth as a serious problem in these countries has coincided with declining teen birth rates (Unicef, 2001). This suggests that the increasing interest in teenage motherhood as an object of concern may be provoked by changing understandings of the role of women in contemporary society. One of the significant shifts which characterises Western fertility patterns has been the increase in the ex-nuptial birth rate (Furstenberg et al., 1987; Statistics New Zealand, 2001). Today, however, in the current climate of sexual freedom for women and a growing rate of ex-nuptial births to white middle-class women, moral judgements about female sexual behaviour in this respect are unlikely to find wide public acceptance. Instead, concerns about teenage motherhood are articulated through the discourses of welfare dependency and social exclusion, the ideological foundation of which is masked by its mediation through scientific literature. The role of science, particularly the reliance on traditional quantitative inquiry, in the contemporary construction of teenage motherhood as problematic is discussed below. 


\section{Science and the problematisation of the teen mother}

While concerns about social exclusion and welfare dependency reflect certain values and beliefs, as mentioned above these have largely been couched in a traditional scientific discourse. This connection with science not only gives such claims legitimacy but, because science is assumed to be impartial and truthtelling, it also makes it difficult to surface underlying political and ideological interests. The French philosopher, Michel Foucault, has highlighted the political nature of knowledge by examining the relationship between knowledge, power and language (1980). As he has demonstrated in his studies of the clinic (1994) and the prison (1995), there is an intimate link between most powerful institutions in society and the production of knowledge and 'truth':

Each society has its régime of truth, its 'general politics' of truth: this is, the types of discourse which it accepts and makes function as true; the mechanisms and instances which enable one to distinguish true and false statements, the means by which each is sanctioned; the techniques and procedures accorded value in the acquisition of truth; the status of those who are charged with saying what counts as true. (Foucault, 1980: 131)

In the West dominant claims to knowledge and truth are made by science, and consequently scientific discourses determine (and constrain) how we experience the world. This has major implications for the issue of teen motherhood since the approach to policy development is increasingly evidence-based, as David has pointed out (2001). This is demonstrated in a number of policy documents and reports concerned with teenage motherhood which draw on traditional scientific studies to support their claims (for example, see Department of Corrections, 2001; Social Exclusion Unit, 1999; Unicef, 2001; Jacobsen et al., 2002; Ministry of Social Development, 2004). The argument is that this can be problematic because policy makers can be selective in the evidence that has informed their strategies (David, 2001).

Selective or not, the research which influences policy in the area of teenage motherhood has frequently been condemned for a lack of rigour, suggesting that there should be caution in drawing definite conclusions. For example, a number of authors have highlighted methodological shortcomings such as small sample sizes and opportunistic sampling (Breakwell, 1993), sampling bias and non-randomised trials (Corcoran et al., 2000), a lack of comparison groups of older mothers (Schilmoeller and Baranowski, 1985; McIntyre and CunninghamBurley, 1993), the effects of the researcher on behaviour (Schilmoeller and Baranowski, 1985), a focus on very young teens (Lamb and Elster, 1986) and a lack of or inadequate controls (Simkins, 1984; Buchholz and Gol, 1986; Grogger and Bronars, 1993; Coley and Chase-Lansdale, 1998).

Underpinning these criticisms, however, is the implication that, if only such methodological flaws could be eliminated, the 'better' science that results would produce a more exact truth about teenage mothers. The idea that a more accurate 
analysis of the effects of teenage motherhood can be achieved is evidenced by the earnest attempts to minimise the impact of background variables by comparisons between sisters (Geronimus and Korenman, 1992; Geronimus, 1997; Hoffman et al., 1993), cousins whose mothers are sisters (Geronimus et al., 1994), teen mothers of singletons and twins (Grogger and Bronars, 1993), and with teenagers who have had miscarriages (Hotz et al., 1997). However, it is very likely that such persistent determination to produce rigorous knowledge about teenage mothers compounds the pathologisation of these young women which some of these very researchers appear to condemn (for example, see Furstenberg et al., 1987). This is significant in view of evidence that the stigma surrounding teenage motherhood can prevent young mothers seeking help with their children (Phoenix, 1991).

Partly because of these issues, the notion of early motherhood as a major problem is increasingly being contested, albeit to varying degrees. One argument is that the seriousness of the problem has been grossly overstated with some scholars calling the preoccupation with teen fertility a 'moral' (Blaikie, 1995: 641) or an 'academic' panic (Griffin, 1993: 159). The comment by an experienced researcher in this field that there has been the emergence of a 'veritable industry' in this area would seem to support these views (Furstenberg, 1991: 127).

There is now widespread agreement that teenage birth is an outcome of, or closely associated with, poverty, disadvantage and/or a lack of opportunities (Geronimus, 1991; Furstenberg, 1991; Ruddick, 1993; Moore et al., 1997; Social Exclusion Unit, 1999; Fergusson and Woodward, 2000; Smithbattle, 2000; McLeod, 2001; Graham and McDermott, 2006). The link between poverty and teen birth is also demonstrated by spatial analyses of the geographic distribution of teen births in both the UK (McCulloch, 2001) and NZ (Wilson et al., 1996). Even in the Netherlands, which has one of the lowest rates of teen birth in the world, 78 per cent of these mothers are at the bottom of the socio-economic ladder (Unicef, 2001).

The idea that teen motherhood is problematic ignores the possibility that teenage women weigh up their opportunity costs when they continue a pregnancy to term (Geronimus, 1991), no doubt in much the same way as older women who opt for later parenthood. This means that since the young women are largely from disadvantaged and impoverished backgrounds, attempts to encourage them to delay childbearing may not only be difficult but counterproductive. A number of scholars have highlighted the dangers of encouraging delay without the introduction of other initiatives that make delay advantageous (Simms, 1993; Geronimus, 1997). As Furstenberg says, '[e]arly childbearing owes its persistence to the fact that many women - not just disadvantaged black youth - have relatively little to lose by having a first birth in their teens or early 20s' (1991: 136).

The failure of research in this field to present more than a one-dimensional picture largely reflects the dominance of quantitative studies which are unable to capture the thoughts and feelings of teenage mothers themselves. However, these 
mothers have more recently found voice through a growing body of qualitative research which on the whole tells a very different story. In contrast to the bleakness which typifies the findings of the quantitative science, young mothers in these interview studies see themselves as making a success of their lives in a variety of ways. For example, according to participants, having a baby provoked positive life changes such as getting off drugs and alcohol (Anderson, 1990; Arenson, 1994; Rains et al., 1998; Lesser et al., 1998), reconnecting with their families (Arenson, 1994; Goodwin, 1996), improved self-esteem (Arenson, 1994), and/or a sense of direction and purpose (Goodwin, 1996; Hanna, 2001; Schultz, 2001). Countering the view that teenagers are ill prepared for parenthood, interview studies found that most young women were proud to be parents (Kirkman et al., 2001), keen to be good parents (Arenson, 1994; Goodwin, 1996; Lesser et al., 1998; Clarke, 1999) and found motherhood enjoyable and/or satisfying (Lamanna, 1999; Hanna, 2001; Kirkman et al., 2001). Ironically, in view of the anxiety about welfare dependency, there is evidence that by having a baby mothers have claimed independence and/or adult responsibilities (Buchholz and Gol, 1986; Davies et al., 1999).

In spite of this growing body of knowledge highlighting the young women's perspectives, as Graham and McDermott (2006) have identified, findings from qualitative inquiry are rarely cited in government documents or reports. This is not only because such studies may pose a challenge to the official orthodoxy regarding teenage mothers, but it also reflects a common perception that qualitative research is less rigorous and accurate. Instead, quantitative science, which takes little account of the contextual nature of human behaviour, has become increasingly enacted through the political processes in terms of policy development. The danger is that this results in flawed or inadequate policy decisions which then may inform the practices of social workers and health care providers in their work with families. For example, science which highlights the negative aspects only of teen parenthood, has been used to sanction the beliefs of politicians and policy makers that teen motherhood results in social exclusion and welfare dependency. As a result, the idea of social exclusion and welfare dependency have become widely accepted as the inevitable outcomes of teenage motherhood. It is these two dominant discourses which are discussed next.

\section{Welfare dependency and social exclusion}

The claim by Geronimus (1997) that concern about teenage motherhood is shared by people from both ends of the political spectrum hints at a common underlying factor. The privileging of Western values such as economic success and social status explains, on the one hand, the Conservatives' anxiety about teen mothers' state dependency and labour market 'avoidance' (for example, see Simcock, 2002; Newman, 2001, 2002), and on the other, the Liberals' concern about education 
and training curtailment (see Baragwanath, 1998; Maharey, 2001; Ministry of Education, 2001). A number of recent US studies in which the economic costs to the taxpayer and the career costs to the individual of early childbearing are quantified support this view (see studies in Maynard, 1997).

But at the heart of these two perspectives is a shared concern about welfare dependency. Since the turn of the 2oth century, there has been a transformation from the deserving/undeserving poor of the philanthropic tradition to a focus on the dichotomy of dependence/independence (Leonard, 1997). In their genealogy of dependency, Fraser and Gordon (1994) have traced shifts in usage of the term dependency over time, from a socially approved to a highly stigmatised condition. Today, they claim, new understandings of dependency are reflected:

in the growing numbers of relatively prosperous women [who] claim the same kind of independence that men do while a more stigmatized but still feminized sense of dependency attaches to groups considered deviant and superfluous. Not just gender but also racializing practices play a major role in these shifts, as do changes in the organization and meaning of labor. (Fraser and Gordon, 1994: 312)

Underpinning this view of dependency are the political imperatives of a liberal welfare model, since this system is common to the US, UK and NZ in which teenage birth rates are seen as most problematic. In contrast with a more generous social democratic welfare provision (interestingly in countries such as Sweden, Netherlands, Denmark where teen birth rates are among the lowest), the liberal welfare model has never had strong middle-class support (EspingAndersen, 1990). Because, as Esping-Andersen argues, the middle classes have failed to be 'wooed from the market to the state', the market is privileged in these countries, isolating and distancing those who have social responsibilities (ibid.: 31).

It has been argued that the welfare state has a divisive function so that the common problems of living under capitalism appear as the individual problems of particular social groups (O'Brien and Penna, 1998). This means that when economic policies impact adversely on the ability of a family to be self supporting, then parents can be conveniently scapegoated as lazy, lacking initiative or dependent on the state. The privileging of economic independence underpins persistent governmental practices, particularly in the US, where, regardless of the age of their youngest child, teen mothers can be required by law to return to school, ${ }^{3}$ or - in some situations - training or work programmes (Pearce, 1993). In the UK the government's objective is to have 60 per cent of teen mothers in work or education by 2010 (Social Exclusion Unit, 2002). New Zealand policies have never overtly insisted that teenage mothers participate in educational activities or work soon after the birth; however, the 'success' of the US welfare to work schemes has over the years informed a number of political discourses in New Zealand (Hubbard, 1997; The Dominion, 1998; Kilroy, 1998; Rich, 2003). 
This is significant for teen mothers because education and labour market participation are increasingly employed as mechanisms of social inclusion within policy and governmental discourses both internationally (OECD, 2003; Social Exclusion Unit, 1999, 2002) and in New Zealand (Ministry of Social Development, 2001; Maharey, 2002; Rich, 2003). As David says:

[s] ocial inclusion is increasingly defined in terms of access to work or employment ... regardless of family responsibilities such as parenthood. Education and training are identified as necessary to enable young people to learn how to find work rather than rely on social security to deal with potential poverty. (2001: 10)

According to some scholars, this marks a move away from the traditional welfare objectives of equality and the redistribution of wealth under the British Labour party (Lister, 1998; Powell, 2000; Huntington and Bale, 2002). The pathway to independence and opportunity is through higher education and the labour market. This is also reflected in New Zealand where there has been a clearly identified shift from a traditional redistributive social welfare model to a social development approach (Maharey, 2002). This new welfare model is underpinned by an emphasis on economic growth and epitomised by the 'primacy of work' (ibid: 13).

This 'global mantra' of paid employment (David, 2001: 9) is ironic since the primary purpose behind the introduction in 1973 in New Zealand of the Domestic Purposes Benefit ${ }^{4}$ - with strong cross-party political support (Elworthy, 1988) - was so that sole parents did not have to go out to work (Goodger and Larose, 1998). Similarly in the US, Aid to Families with Dependent Children (ADFC) aimed to provide an income so sole parents did not have to find paid work (Fraser and Gordon, 1994). Today, however, this position has little support from politicians and commentators, with some arguing that state benefits encourage ex-nuptial childbirth, particularly for teenagers (Bain, 1999a, 1999b; Schnauer, 2000; New Zealand Herald, 2001; Murray, 2001; Woodhouse, 2001). This persists in spite of claims that there is no good evidence that the provision of state support affects choices about single parenthood (Goodger, 1998; Kelly, 1999).

It is no coincidence that this has occurred at a time when middle-class women are gaining higher education and professional careers. Although historically working-class women have often had to work outside the home to supplement the family income, it was particularly when middle-class women began to join the labour market and delay childbearing that normalised the female career path and rendered problematic the lives of stay-at-home (young) mothers, particularly those on welfare. Through no fault of their own, teenage mothers are stigmatised and condemned by a system in which '[n] ormality is defined in terms of white middle-class linguistic and cultural practices and family forms' (Griffin, 1993:38). 
As an international report into teen births says:

teenage parenthood has come to be regarded as a significant disadvantage in a world which increasingly demands an extended education, and in which delayed childbearing, smaller families, two income households, and careers for women are increasingly becoming the norm. (Unicef, 2001: 5-6)

The effect of this strong emphasis on higher education and workforce participation is that concerns of gender are valued less than concerns about the market (Esping-Andersen, 1990; David, 2001). In other words, childrearing, an activity which is still predominantly undertaken by women, is accorded little value by society. According to Fraser, it is a paradoxical welfare system which constructs clients as mothers:

[y] et ... does not honor these women. On the contrary, instead of providing them a guaranteed income equivalent to a family wage as a matter of right, it stigmatises, humiliates, and harasses them. In effect, it decrees simultaneously that these women must be and yet cannot be normative mothers. (Fraser, 1989: 153)

In the past, it was women who stayed at home to raise their children who were considered the norm. Women working outside the home were frowned upon, not least because of the damaging effects their absence was considered to inflict on their young children (Bowlby, 1951, 1969). Today - after a few decades - even a conservative politician can argue, on the basis of science, that when mothers are in the paid workforce, children are unaffected (see Rich, 2003: 12). The traditional view that 'a mother's place is in the home' is also challenged by glowing media stories in New Zealand about teenage mothers going to school and/or university while their children are still young (for example, see Haines, 2001; Greeks, 2001; Dekker, 2002, 2003). In contrast, those teenage mothers that choose to stay home with their children, as Phoenix (1991) found most prefer to do, are totally absent in the popular media.

Although they may be invisible to the outside world, it is very likely that teenage mothers feel they are making their own contribution to society through their active involvement in raising their children (for example, see Kirkman et al., 2001). It would be interesting to know if they themselves feel socially excluded as they go about this important job, although there is enough evidence to show they feel stigmatised or condemned (Phoenix, 1991; Kirkman et al., 2001; Schultz, 2001). On the other hand, although income from state benefits tends to be parsimonious, there may be little economic advantage for many of these women if they work outside the home. As Lister suggests, there are important questions about the value of social inclusion in a 'profoundly unequal labour market' (1998: 221). It should not be surprising to find that motherhood is a preferable option if the alternative is to work for inadequate wages. The argument that most people have 'working lives, not careers' (Knoll, 1998: 2) highlights the way in which 
middle-class aspirations for well-paid professional jobs have come to set the parameters for social inclusion.

According to O'Brien and Penna, marginalisation and exclusion are 'inevitably accompanied by resistance and conflict which gives rise to political struggle over meaning and experience of exclusion' (1998: 131). If this is the case, teenagers who become mothers can be seen as actively resisting the current political and social imperatives of higher education and workforce participation to which middle-class women have largely succumbed. But it is a measure of their very success in this resistance which ensures their positioning by others as a threat to the values and norms associated with economic independence and social status, which in contemporary Western society are gained only through paid employment and a professional career.

\section{Conclusion}

The presentation of teenage motherhood as a significant social or public health problem at a time of declining teen birth rates in the UK, US and NZ highlights the ideologies underpinning contemporary beliefs about welfare dependency and social inclusion which inform contemporary social policy in this area. In particular, the shift from a redistributive welfare model to one based on economic growth has seen traditional ideas about childrearing quietly cast aside in the interests of increased female workforce participation and economic independence. From this perspective it seems that teenage mothers have been vilified because they are seen to be actively choosing an alternative path to their middle-class peers, one that does not satisfy contemporary governmental objectives.

However, in contrast to the aspirations of their educated middle-class counterparts, working outside the home for many young mothers does not mean a highly paid professional job following on from higher education. The reality is more likely to be menial work for poor wages. To insist that teen mothers enter the workforce on this basis while their children are young puts them at a double disadvantage as they struggle to make ends meet and at the same time provide a satisfactory home for their families. On the other hand, if they successfully resist the pressure to return to work or schooling they face implied criticism when confronted with the regular news stories extolling the virtues of teen mothers who return to school and university while their children are still young.

This highlights the importance of ensuring that the voices of teen mothers are given equal weight in the scientific debate and policy development around teen birth. Reliance on quantitative studies which overlook the contextual nature of human behaviour can only give a distorted and limited understanding of the lives of these women. This is demonstrated by the very different and largely positive stories which emerge from the interview studies with the young mothers 
themselves, but which rarely find their way into policy documents or reports. However, this process is unlikely to be unproblematic, particularly if, as Popay et al. (1998: 621) contend, lay knowledge poses a challenge to those who 'claim the status of either research or policy expert'. The struggle over language and meaning at the site of knowledge creation is an indication of the high stakes involved, as some scholars have pointed out (Weedon, 1987; O'Brien and Penna, 1998). As we have seen, however, in the teen motherhood debate, the tendency is to privilege the quantitative science which is seen as more sound, more expert. As Foucault argues, there are

a whole set of knowledges that have been disqualified as inadequate to their task or insufficiently elaborated: naïve knowledges located low down on the hierarchy, beneath the required level of cognition or scientificity... it is through the re-appearance of this knowledge, of these local popular knowledges, these disqualified knowledges that criticism performs its work. (Foucault, 1980: 82)

This raises profound questions about the processes of knowledge creation and how science has been used 'not to explain reality, but to produce, control and normalise it' (Braidotti et al., 1994: 31). The increasing trend to evidence-based policy development means not only that the ideologies and values which underpin policy decisions are masked, but also that when evidence is partial then the knowledge produced is seriously flawed. This has important implications for appropriate service provision and delivery since this is generally an outcome of policy. If society is really concerned about teen motherhood, then support rather than stigmatisation through the domination of science is a more compassionate and effective approach.

There are increasing calls within policy and research circles concerned with maternal and infant health for a shift from a problem-based approach to research on resilience (Winfield, 1995; Smithies and Bidrose, 2000; Merrick, 2001). The advantages of a strengths-based approach are a reduction both in stigma (Rhodes and Johnson, 2000) and in the negative images of teenage parents which can be 'a self-fulfilling prophecy' (Furstenberg et al., 1987: 152). However, this may mean experts have to relinquish some control over the means and method of knowledge production. Teenage mothers have the right to be actively involved in determining the questions which they think need asking and answering, and, with guidance, the methods by which this should be done.

\section{Notes}

1 The eugenics movement emerged at the turn of the 19th century as the scientific study for 'the improvement of the human race by better breeding' (Allen, 1995, citing Davenport, 1911). Today, while the teen motherhood 'problem' is still closely associated with poverty and disadvantage, there is also a racial dimension to the debate which has eugenic implications. Although race is not the focus of this article, it is arguably no coincidence that countries 
such as NZ and US, where teenage motherhood is seen as problematic, are often those whose rates of teen birth among indigenous and/or non-white groups are significantly higher than that of their white peers.

2 The modal age range of NZ mothers of European descent is now 30-34 years, succeeding the rate at 25-29 years for the first time on record (Ministry of Social Development, 2004).

3 Under the Family Support Act 1988, each state must require welfare recipients who are teen mothers to return to school full time regardless of the age of their youngest child (Pearce, 1993).

4 Since 1973, the Domestic Purposes Benefit (DPB) has provided financial support for single parents in New Zealand, the majority of whom are women (Beaglehole, 1993).

\section{References}

Allen, G. (1995), 'Eugenics comes to America', in R. Jacoby and N. Glauberman (eds), The Bell Curve Debate: History, Documents, Opinions, New York: Random House, pp. 441-75.

Allison, R. and Hall, S. (2001), 'Battle to cut teenage pregnancy rate', Guardian, 22 February, available at www.guardian.co.uk/Archive/Article/o,4273,4140036,oo.html

Anderson, N. (1990), 'Pregnancy resolution decision in juvenile detention', Archives of Psychiatric Nursing, 4: 5, 325-31.

Andrew, K. (2000), 'Teen pregnancy, STDs “crisis", The Press, 25 November.

Arenson, J. (1994), 'Strengths and self-perceptions of parenting in adolescent mothers', Journal of Pediatric Nursing, 9: 4, 251-7.

Ariès, P. (1973), Centuries of Childhood, translated from the French by Robert Baldick, London: Jonathan Cape.

Bain, H. (1999a), 'DPB “shouldn't be lifestyle choice”, The Dominion, 4 June, 2.

Bain, H. (1999b), 'DPB data "tragic reflection of welfare state"', The Dominion, 10 June.

Baragwanath, S. (1998), 'Making the system work for the at-risk student', Social Policy Journal of New Zealand, 11: December, 95-109.

Beaglehole, A. (1993), Benefitting Women: Income Support for Women 1893-1993, Wellington: Social Policy Agency.

Blaikie, A. (1995), 'Motivation and motherhood: past and present attributions in the reconstruction of illegitimacy', The Sociological Review, 43: 4, 641-57.

Botting, B., Rosato, M. and Wood, R. (1998), 'Teenage mothers and the health of their children', Population Trends, 93: Autumn.

Bowlby, J. (1951), Maternal Care and Child Health, Geneva: World Health Organisation.

Bowlby, J. (1969), Attachment and Loss, Vol I: Attachment, New York: Basic Books.

Braidotti, R., Charkiewicz, E., Häusler, S. and Wieringa, S. (1994), Women, the Environment and Sustainable Development: Towards a Theoretical Synthesis, London: Zed Books.

Breakwell, G. (1993), 'Psychological and social characteristics of teenagers who have children', in A. Lawson and D. Rhode (eds), The Politics of Pregnancy: Adolescent Sexuality and Public Policy, New Haven: Yale University Press, pp. 159-73.

Buchholz, E. and Gol, B. (1986), 'More than playing house: a developmental perspective on the strengths in teenage motherhood', American Journal of Orthopsychiatry, 56: 3, 347-59.

Burt, C. (1938), The Young Delinquent, London: University of London Press.

Campbell, L. (2001), 'A brilliant mistake', Guardian, 2 January, available at www.guardian. co.uk/Archive/Article/o,4273,4111486,oo.html

Card, J. and Wise, L. (1978), 'Teenage mothers and teenage fathers: the impact of early childbearing on the parents' personal and professional lives', Family Planning Perspectives, 1: 4, 199-204.

Chapple, W. (1903), The Fertility of the Unfit, Christchurch: Whitcombe \& Tombs.

Checkland, S. and Checkland, E. (eds) (1974), The Poor Law Report of 1834, Harmondsworth: Penguin Books. 
Clarke, S. (1999), 'What do we know about unmarried mothers?', in J. Wong and D. Checkland (eds), Teen Pregnancy and Parenting: Social and Ethical Issues, Toronto: University of Toronto Press, pp. 10-24.

Coley, R. and Chase-Lansdale, P. (1998), 'Adolescent pregnancy and parenthood: recent evidence', American Psychologist, 53: 2, 152-66.

Corcoran, J., Franklin, C. and Bennett, P. (2000), 'Ecological factors associated with adolescent pregnancy and parenting', Social Work Research, 24: 1, 29-39.

Cunnington, E. (1916a), 'Women in our criminal courts: the need for reform', Maoriland Worker, 18 October.

Cunnington, E. (1916b), Maoriland Worker, 29 November.

David, M. (2001), “"Teenage parenthood is bad for parents and children”: restructuring the governing patterns of parents and children, education, employment and welfare policies', Paper prepared for Keele conference, June 2001.

Davies, L., McKinnon, M. and Rains, P. (1999), “'On my own”: a new discourse of dependence and independence from teen mothers', in J. Wong and D. Checkland (eds), Teen Pregnancy and Parenting: Social and Ethical Issues, Toronto: University of Toronto Press, pp. 38-51.

Dekker, D. (2002), 'Teenage mums: turning point', The Evening Post, 16 February, 23.

Dekker, D. (2003), 'Benefits to society', The Dominion Post, 8 March.

Department of Corrections (2001), 'About time: turning people away from a life of crime and reducing offending', report from the Department of Corrections to the Minister of Corrections, Department of Corrections, Wellington.

Dickson, N., Sporle, A., Rimene, C. and Paul, C. (2000), 'Pregnancies among New Zealand teenagers: trends, current status and international comparisons', New Zealand Medical Journal, 23 June, 241-5.

Elworthy, S. (1988), 'Social change and the state: the emergence of a benefit for unmarried mothers in New Zealand', a long essay submitted for the degree of BA (Hons) in history at the University of Otago, Dunedin.

Esping-Andersen, G. (1990), The Three Worlds of Welfare Capitalism, Cambridge: Polity Press.

Fergusson, D. and Woodward, L. (1999), 'Maternal age and educational and psychological outcomes in early adulthood', Journal of Child Psychology and Psychiatry, 40: 3, 479-89.

Fergusson, D. and Woodward, L. (2000), 'Teenage pregnancy and female educational underachievement: a prospective study of a New Zealand birth cohort', Journal of Marriage and the Family, 62: February, 147-61.

Foucault, M. (1980), Power/Knowledge: Selected Interviews and other Writings 1972-1977, ed. C. Gordon, New York: Pantheon Books.

Foucault, M. (1994), 'The Birth of the Clinic: An Archaeology of Medical Perception', trans. A. M. Sheridan-Smith, New York: Vintage Books.

Foucault, M. (1995), Discipline and Punish: The Birth of the Prison, 2nd edn, New York: Vintage Books.

Fraser, N. (1989), Unruly Practices: Power, Discourse and Gender in Contemporary Social Theory, Cambridge: Polity Press.

Fraser, N. and Gordon, L. (1994), 'A genealogy of dependency: tracing a keyword of the US welfare state', Signs, 19: 2, 309-36.

Fraser, A., Brokert, J. and Ward, R. (1995), 'Association of young maternal age with adverse reproductive outcomes', The New England Journal of Medicine, 332: 17, 1113-17.

Furstenberg, F. (1991), 'As the pendulum swings: teenage childbearing and social concern', Family Relations, 40: 127-138.

Furstenberg, F., Brooks-Gunn, J. and Morgan, S. (1987), Adolescent Mothers in Later Life, Cambridge: Cambridge University Press.

Geronimus, A. (1991), 'Teenage childbearing and social reproductive disadvantage: the evolution of complex questions and the demise of simple answers', Family Relations, 40: 4, 463-71.

Geronimus, A. (1997), 'Teenage childbearing and personal responsibility: an alternative view', Political Science Quarterly, 112: 3, 405-30.

Geronimus, A. and Korenman, S. (1992), 'The socio-economic consequences of teen childbearing reconsidered', Quarterly Journal of Economics, 107: 4, 1187-214. 
Geronimus, A., Korenman, S. and Hillemeier, M. (1994), 'Does young maternal age adversely affect child development? Evidence from cousin comparisons in the United States', Population and Development Review, 20: 3, 585-609.

Goodger, K. (1998), 'Maintaining sole parent families in New Zealand: an historical review', Social Policy Journal of New Zealand, 10: June, 122-53.

Goodger, K. and Larose, P. (1998), 'Changing expectations: sole parents and employment in New Zealand', paper presented to 6th Australasian Institute of Family Studies Conference, Changing Families, Challenging Futures, Melbourne, November.

Goodwin, D. (1996), "'He hapu te whare tangata”: support for young Maori mothers during pregnancy, birth and motherhood', Master of Social Work thesis, Massey University, Palmerston North, New Zealand.

Graham, H. and McDermott, E. (2005), 'Qualitative research and the evidence-base of policy: Insights from studies of teenage mothers in the UK', Journal of Social Policy, 35: 1, 21-38.

Greeks, P. (2001), 'Babes in the school classroom', The Dominion, 30 July.

Griffin, C. (1993), Representations of Youth: The Study of Youth and Adolescence in Britain and America, Cambridge: Polity Press.

Grogger, J. (1997), 'Incarceration-related costs of early childbearing', in R. Maynard (ed.), Kids Having Kids: Economic Costs and Social Consequences of Teen Pregnancy', Washington, DC: The Urban Institute Press, pp. 231-55.

Grogger, J. and Bronars, S. (1993), 'The socio-economic consequences of teenage childbearing: findings from a natural experiment', Family Planning Perspectives, 25: 4, 156-61.

Haines, L. (2001), 'Teen mums head for university', The Dominion, 25 August, 1.

Hanna, B. (2001), 'Negotiating motherhood: the struggles of teenage mothers', Journal of Advanced Nursing, 34: 4, 456-64.

Hoffman, S., Foster, E. and Furstenberg, F. Jr (1993), 'Reevaluating the costs of teenage childbearing', Demography, 30: 1, 1-13.

Holt, J. and Johnson, S. (1991), 'Developmental tasks: a key to reducing teenage pregnancy', Journal of Pediatric Nursing, 6: 3, 191-6.

Hotz, V., McElroy, S. and Sanders, S. (1997), 'The impacts on teenage childbearing on the mothers and the consequences of those impacts for government', in R. Maynard (ed.), Kids Having Kids: Economic Costs and Social Consequences of Teen Pregnancy', Washington, DC: The Urban Institute Press, pp. 56-90.

Howard, S. (1999), 'Adolescent birth in New Zealand', in I. Pool and K. Johnstone (eds), 'The life courses of New Zealand women: fertility, family formation and structure, fertility regulation, education, work and economic wellbeing', papers presented at a seminar at the Ministry of Women's Affairs, 8 June 1999 [Hamilton], Population Studies Centre, University of Waikato, pp. 35-40.

Hubbard, A. (1997), 'Making the welfare system work', Sunday Star Times, 16 March.

Huntington, N. and Bale, T. (2002), 'New Labour: New Christian democracy?', The Political Quarterly, 73: 1, 44-50.

Jacobsen, V., Mays, N., Crawford, R., Annesley, B., Christoffel, P., Johnston, G. and Durbin, S. (2002), 'Investing in well-being: an analytical framework', New Zealand Treasury Working Paper 02/23, Treasury, Wellington.

Jaffee, S., Caspi, A., Moffitt, T., Belsky, J. and Silva, P. (2001), 'Why are children born to teen mothers at risk for adverse outcomes in young adulthood? Results from a 20 year longitudinal study', Development and Psychopathology, 13: 377-97.

Kelly, D. (1999), 'A critical feminist perspective on teen pregnancy and parenthood', in J. Wong and D. Checkland (eds), Teen Pregnancy and Parenting: Social and Ethical Issues, Toronto: University of Toronto Press, pp. 52-70.

Kilroy, S. (1998), 'Welfare revamp leans on US model', The Dominion, 14 May.

Kirkman, M., Harrison, L., Hillier, L. and Pyett, P. (2001), “'I know I'm doing a good job"': canonical and autobiographical narratives of teenage mothers', Culture, Health and Sexuality, 3: 3, 279-94.

Knoll, T. (1998), 'The stigmatisation of unwed motherhood: an anomaly of late modernity', paper presented at the 14th World Congress of Sociology, Montreal. 
Lamanna, M. (1999), 'Living the postmodern dream: adolescent women's discourse in relationships, sexuality, and reproduction', Journal of Family Issues, 20: 2, 181- 217.

Lamb, M. and Elster, A. (1986), 'Parental behaviour of adolescent mothers and fathers', in A. Lamb and M. Elster (eds), Adolescent Fatherhood, Hillsdale, NJ: Lawrence Erlbaum Associates, pp. 89-106.

Leonard, P. (1997), Postmodern Welfare: Reconstructing an Emancipatory Project, London: Sage Publications.

Lesser, J., Anderson, N. and Koniak-Griffin, D. (1998), “'Sometimes you don't feel ready to be an adult or a mom": the experience of adolescent pregnancy', Journal of Child and Adolescent Psychiatric Nursing, 11: 1, 7-16.

Lister, R. (1998), 'From equality to social inclusion: New Labour and the welfare state', Critical Social Policy, 18: 2, 215-25.

MacKenzie, D. (1981), 'Statistics in Britain 1865-1930: the social construction of scientific knowledge', Edinburgh University, Edinburgh.

Maharey, S. (2001), 'Why we need the DPB', The Dominion, 5 July.

Maharey, S. (2002), 'Where for welfare? Social development and refurbishment of the welfare state', available at http://www.executive/govt.nz/speech

Maynard, R. (ed.) (1997), Kids Having Kids: Economic Costs and Social Consequences of Teen Pregnancy, Washington, DC: The Urban Institute Press.

McCulloch, A. (2001), 'Teenage childbearing in Great Britain and the spatial concentration of poverty', Journal of Epidemiology and Community Health, 55: 1, 16-22.

McIntyre, S. and Cunningham-Burley, S. (1993), 'Teenage pregnancy as a social problem: a perspective from the United Kingdom', in A. Lawson and D. Rhode (eds), The Politics of Pregnancy: Adolescent Sexuality and Public Policy, New Haven: Yale University Press, pp. 59-73.

McLeod, A. (2001), 'Changing patterns of teenage pregnancy: population based study of small areas', British Medical Journal, 323: 199-203.

Merrick, E. (2001), Reconceiving Black Adolescent Childbearing, Colorado: Westview Press.

Ministry of Education (2001), 'Whatever you do, don't push a pram before your time', advertisement, Sunday Star Times, 26 August.

Ministry of Health (1998), 'Child health programme review', Ministry of Health, Wellington.

Ministry of Social Development (2002), 'Improving wellbeing for all New Zealanders: briefing to the incoming Minister', Ministry of Social Development, Wellington.

Ministry of Social Development (2004), 'Children and young people: indicators of wellbeing in New Zealand', Ministry of Social Development, Wellington.

Ministry of Social Policy (2001), 'The social report/Te purongo oranga tangata 2001', Ministry of Social Policy, Wellington.

Moore, K., Morrison, D. and Greene, A. (1997), 'Effects on the children born to teenage mothers', in R. Maynard (ed.), Kids Having Kids: Economic Costs and Social Consequences of Teen Pregnancy', Washington, DC: The Urban Institute Press, pp. 145-80.

Murray, C. (2001), 'The curse of the DPB', The Dominion, 27 June.

Myles, M. (1968), A Textbook for Midwives, 6th edn, Edinburgh: E.\& S. Livingstone Ltd.

Neale, E. (1924), 'A New Zealand study in sex delinquency', The NZ Journal of Science and Technology, 7: 1, 19-24.

New Zealand Herald (2001), 'Shirking dads too readily accepted', editorial, 18 June.

NZ Government (2001), 'Pathways to opportunity: Nga ara whai oranga. From social welfare to social development', Wellington.

NZPD (1885), Vol. 88 (18 July-9 August).

Newman, M. (2001), 'Kids caught in DPB dependency trap', The Dominion, 25 July, 12.

Newman, M. (2002), 'Welfare reform would combat teen pregnancy', available at http://www.act.org.nz/item.jsp?id=22563.

O’Brien, M. and Penna, S. (1998), Theorising Welfare: Enlightenment and Modern Society, London: Sage Publications.

OECD (2003), 'Society at a glance: OECD social indicators', OECD, France.

Paltridge, A. (2002), 'Teens binge-drinking more - report', The Evening Post, 22 February. 
Pearce, D. (1993), 'Children having children: teenage pregnancy and public policy from the woman's perspective', in A. Lawson and D. Rhode (eds), The Politics of Pregnancy: Adolescent Sexuality and Public Policy, New Haven: Yale University Press, pp. 46-59.

Peckham, S. (1993), 'Preventing unplanned teenage pregnancies', Public Health, 107: 125-33.

Philipp, E. (1946), 'Juvenile delinquency in New Zealand: a preliminary study', Council for Educational Research, Christchurch, New Zealand.

Phoenix, A. (1991), Young Mothers?, Cambridge: Polity Press.

Popay, J., Williams, G., Thomas, C. and Gatrell, A. (1998), 'Theorising inequalities in health: the place of lay knowledge', Sociology of Health and Illness, 20: 5, 619-44.

Powell, M. (2000), 'New Labour and the third way in the British welfare state: a new and distinctive approach?', Critical Social Policy, 20: 1, 39-60.

Rains, P., Davies, L. and McKinnon, M. (1998), 'Taking responsibility: an insider view of teen motherhood', Families in Society, 79: 3, 308-19.

Rhodes, R. and Johnson, M. (2000), "'Students" perceptions of single parents and social injustice: a women's issue', Affilia, 15: 3, 434-46.

Rich, K. (2003), 'Saving the next generation from welfare dependency', discussion paper by Katherine Rich, National Party Welfare spokesperson, National [Party], Wellington.

Ritchie, J. and Ritchie, J. (1984), The Dangerous Age: Surviving Adolescence in New Zealand, Sydney: Allen \& Unwin.

Robertson, C. (1998), 'Teen abortions in thousands', The Evening Post, 29 December.

Ruddick, S. (1993), 'Procreative choice for adolescent women', in A. Lawson and D. Rhode (eds), The Politics of Pregnancy: Adolescent Sexuality and Public Policy, New Haven: Yale University Press, pp. 126-43.

Samson, A. (2000), 'Maori teenage birth rate soars', The Dominion, 27 June, 1.

Scally, G. (2002), 'Too much too young? Teenage pregnancy is a public health, not a clinical, problem', International Epidemiological Association, 31: 3, 554-5.

Schilmoeller, G. and Baranowski, M. (1985), 'Childrearing of firstborns by adolescent and older mothers', Adolescence 20: 80, 805-22.

Schnauer, P. (2000), 'But what about social policies such as the DPB?', The Herald, September.

Schultz, K. (2001), 'Constructing failure, narrating success: rethinking the "problem" of teen pregnancy', Teachers College Record, 103: 4, 582-607.

Simcock, B. (2002), 'Employment is the cure', The Evening Post, 16 January.

Simkins, L. (1984), 'Consequences of teenage pregnancy and motherhood', Adolescence, 19: 73, 39-54.

Simms, M. (1993), 'Adolescent pregnancy among blacks in the United States: why is it a policy issue?', in A. Lawson and D. Rhode (eds), The Politics of Pregnancy: Adolescent Sexuality and Public Policy, New Haven: Yale University Press, pp. 241-56.

Slater, J. (1999), 'Will labour deliver on teenage mums?', Times Educational Supplement, 19 March, No. 4316.

Smithbattle, L. (2000), 'The vulnerabilities of teenage mothers: challenging prevailing assumptions', Advances in Nursing Science, 23: 1, 29-40.

Smithies, R. and Bidrose, S. (2000), 'Debating a research agenda for children for the next five years', Social Policy Journal of New Zealand, 15: 41-54.

Social Exclusion Unit (1999), 'Teenage pregnancy: Report by the Social Exclusion Unit', Office of the Deputy Prime Minister, London.

Social Exclusion Unit (2002), 'GFS platform conference - teenage pregnancy strategy', available at www.socialexclusion.gov.uk

Special Committee on Moral Delinquency in Children and Adolescents (1954), 'Report of the Special Committee on moral delinquency in children and adolescents', R. E. Owen, Government Printer, Wellington.

Stanley Hall, G. (1904), Adolescence, Its Psychology and Its Relations to Physiology, Anthropology, Sociology, Sex, Crime Religion and Education, New York: D. Appleton \& Company.

Statistics New Zealand (2001), 'Socio-economic factors and the fertility of New Zealand women: a study of data from the New Zealand 1996 census of population and dwellings', Statistics New Zealand, Wellington. 
The Dominion (1998), 'ACT promotes tough message on welfare', 16 March.

Turia, T. (2004), 'Celebrate the circle of life', The Dominion Post, 16 November.

Unicef (2001), 'A league table of teenage births in rich nations', Innocenti Report Card, Issue No. 3, Florence.

Van Beynen, M. (2001), 'Chlamydia found in high schools', The Press, 7 November, 4.

Walker, J., MacGillivray, I. and MacNaughton, M. (eds) (1976), Combined Textbook of Obstetrics and Gynaecology, 9th edn, Edinburgh: Churchill Livingstone.

Weedon, C. (1987), Feminist Practice and Poststructural Theory, Oxford: Blackwell.

Williams, S., Forbes, J., Mellwaine, G. and Rosenberg, K. (1987), 'Poverty and teenage pregnancy', British Medical Journal, 294: 20-1.

Wilson, N., Clements, M., Bathgate, M. and Parkinson, S. (1996), 'Using spatial analysis to improve and protect the public health in New Zealand: Public health report number 1', Ministry of Health, Wellington.

Winfield, L. (1995), 'The knowledge base on resilience in African-American adolescents', in L. Crockett and A. Crouter (eds), Pathways Through Adolescence: Individual Development in Relations to Social Contexts, Mahwah, New Jersey: Lawrence Erlbaum Associates, pp. $87-118$.

Woodhouse, P. (2001), 'Eastbourne woman launches petition to get DPB axed', Contact, 5 July, 3.

YWCA (2004), 'Respect young mums: young mums campaign', available at: http://www.ywca.org.uk/youngmums 


\title{
Deviant (M)others: The construction of teenage motherhood in contemporary discourse
}

\author{
Wilson, Helen
}

2006

http://hdl.handle.net/10179/9682

22/04/2023 - Downloaded from MASSEY RESEARCH ONLINE 